\title{
POEMS AFTER JUVENAL, CATULLUS \& HORACE
}

\author{
C Mann (Rhodes University)
}

Vanity (after Juvenal)

And now what's the matter, Demetrius? Huddled on a bench, picking at a sandal and gazing gloomily over smoggy Rome you look as miserable as one of your friezes.

One of the better ones, to tell the truth. A cypress, sooty. A Venus, vandalized ... you couldn't have composed it better. I'd call it, Ah woe is me, sans nymphs.

Did someone snap their Grecian chisel? Or chip off the curve of Cupid's smile? I bet that's what you'd tell me if I asked, but I won't, you look far too forbidding.

I know, I know, you're not like that at all. You're sensitive and intelligent and kind and only look unbearably lonely and grim because your patron was seen with a rival.

How you must hate him. The young poseur, all surface without any gravitas, you said, dashing off frescoes for the nouveau riche as if tragedy and the gods had disappeared.

What a life, grovelling for commissions, riddled with envy, doubt and desperation, chip, chip, chipping away, year after year, at stone-leafed vines and blank-eyed gods.

Quite frankly, I could murder your tutor, the one who said you had such potential. Remember? The disaster began in flattery. He needed pupils. Vanity did the rest. 
Go and sell onions, start a whore-house, emigrate to the wilds of barbarous Britain do anything, Demetrius, except more art. Why make us all miserable till you die?

Listen, that Ceres you carved for months is still out of shape. Don't shirk the truth. Your appetite for fame will always exceed the appalling mediocrity of your gifts.

\section{Truth (after Catullus )}

Why are the nicest girls so plain? Don't laugh. Now that liberty has turned to licence in Rome I can't think of a single woman who is both virtuous and beautiful.

Worse still, those brutes, the men. They make me sick. Even senators with good looks, adorable wives, farms in Umbria, Caesar's affection play fast and loose with the truth.

Let the curly-headed young poets versify the shapely white necks of the swans of Tiber's swampland, deluding their patrons that theirs are the truest of beautiful songs.

That's Plato's heady twaddle. Ha! the sows with hairy breasts butting their piglets in the forest are prettier by far than the swans which preen among the reeds.

Pigs! Isn't the filthiest old boar tusking up muck in dung-heaps more honest than a politician? What truth is the poet's moon when offal festers in the forum? 
No, the truth is me, Catullus, me whom money-men threaten and senators malign and sue. Stuff them. The fairest of poems tells the ugliest of truths.

\section{Priapus (after Horace)}

Imagine a banquet in a villa with a roaring fire when all the hills of Rome are white with snow! I lay on my side, drowsed by the dark red wine as silver-tongued Maecenas clapped his hands.

Three dancers came tripping through an arch, curtsied, smiled, then slowly raised their arms. Their eyes were immodestly edged with black, the bangles on their ankles jingled and shone.

Libidius, one perfumed hand below his head, the other still clutching his newest play-script whispered, 'I've been so depressed, Horatius, but thank the gods, love makes things new'.

Ha! I thought to myself, don't make me laugh, a lecherous beast knows more of love than you. Whose secret bedroom's a chamber of mirrors where courtesans come to pleasure his nights?

The dancers ran, leapt and spun on their feet, knelt down, threw back their long black hair and swayed in ways that make men mad. Even sour Bavius spilt wine down his front.

Libidius, at the end, staggered up on his feet and muttering, 'Marvellous, just marvellous!' lunged at the bosom of the giggling Claudia who pulled him stumbling through the arch. 
Maecenas clapped, the Syrian envoys cheered and even the newest of his fat-bellied parasites oozed out a drunken $\mathrm{Ho}$, ho, ho! and warbled in that atrocious Carthaginian accent of his.

Ha, cruel Venus, why do you still deceive us? Why do men stumble off through the arches knowing that at the end of the novelty awaits a lonelier and darker desolation than before?

I stood and wrapping my countryman's cloak around the indigestion growling in my bowels walked in the frozen garden to clear my head and saw Priapus alone on a plinth in the sleet.

Poor fellow, his huge, ridiculous manhood sticking out from under his wooden jerkin had no place to shelter from the icy blasts. A crack along the top was white with snow.

I shivered, turned and walking back to the villa I could have sworn I heard behind the shutters the shrieks of a nymph, feigning consummation while a goat-legged satyr groaned on and on.

Well, what of it. Libidius will be back in spring fleeing his wrinkles and the rage of his wife as he tightens his paunch on a garden bench and dandles a pretty new Claudia on his lap.

Above them Priapus, plastered, painted and oiled, will glower across the city from his leafy nook, a scarecrow from the orchards turned into a god. But what of it. To each his own delusions and pain. 